\title{
Beyond the quality circle: The integration of entrepreneurial action thinking in business organizations
}

\author{
J.G. Kotzé \\ School of Bubiness Leadership, University of South Africa, P.O. Box 392, Pretoria, 0001 Republic of South Africa
}

\begin{abstract}
In the highly uncertain and competitive operating environments of recent times, aninnovative orientation has become essential to all business organizations. This requirement has resulted in the putflication of numerous articles dealing with concepts such as quality circles, action plan teams, and strategy formulation groups. Increasing emphasis is also being placed on the importance of effectiveness rather than efficiency; on working 'smarter' rather than working 'harder'. Different variations of these concepts have also been implemented in some organizations. However, such applications frequently do not yield the anticipated benefits. Such disappointing results can usually be attributed to misconceptions on the part of top management regarding the nature of the different aspects of innovation. The appropriate approach to follow to derive optimum benefit from each aspect is frequently also not clear. An explanatory analysis of each aspect of innovation appropriate to every major level of management is attempted in this article. Finally, an integrated perspective, providing an effective linkage between the identified creativity elements, is developed.
\end{abstract}

\begin{abstract}
'n Innoverende oriëntasie het, in die baie onsekere en hoogs mededingende bedryfsomgewings van die afgelope tyd, noodsaaklik geword vir alle sake-ondernemings. Hierdie vereiste het gelei tot die publikasie van talryke artikels wat begrippe soos gehaltesirkels, aksieplanspanne en strategie-formuleringsgroepe hanteer. Toenemende klem word ook op die belangrikheid van doelmatigheid eerder as doeltreffendheid; op die begrip van 'slimmer' werk eerder as 'harder' werk, geplaas. Verskeie weergawes van hierdie begrippe word ook in sekere organisasies toegepas. Sodanige toepassings lewer egter dikwels nie die verwagte voordele nie. Hierdie teleurstellende resultate kan dikwels toegeskryf word aan wanopvattings aan die kant van topbestuur vir sover dit die aard van die verskillende aspekte van innovasie betref. Die gepaste benadering om te volg om optimale voordeel uit elke aspek te verkry is dikwels ook nie duidelik nie. 'n Verduidelikende ontleding van elke aspek van innovasie wat toepaslik is op elk van die belangrikste bestuursvlakke word in hierdie artikel onderneem. Laastens word 'n geïntegreerde perspektief, wat 'n doelmatige koppeling tussen die geïdentifiseerde kreatiwiteitselemente verskaf, ontwikkel.
\end{abstract}

\section{Introduction}

Entrepreneurial ability is becoming an increasingly valuable commodity in business organizations. An innovative orientation on all levels of management has become accepted as one of the most important characteristics of high performance firms. Such an orientation has traditionally been regarded as especially appropriate to the higher levels of management, viz top managment and higher level middle management.

In recent years, however, some organizations have begun using the creative abilities of lower levels of management as well. Managers and supervisors on these levels are close to operations, enabling them to generate useful suggestions and potential action plans. This has resulted in all levels of management, from first line supervision to top management, becoming involved in either quality circles, action plan teams, or strategy formulation groups.

This desirable development has, unfortunately, given rise to undesirable side-effects. Such effects might be described as confusion on the part of lower levels of management and unrealistic expectations on the part of higher levels of management. Lower level managers do not understand clearly what is expected of them. They also, frequently, are charged with the responsibility of innovative thought and action without posessing the concomitant authority, skill, experience, and opportunity to discharge such responsibility. Top management, having accepted the principle that all levels of management can contribute towards entrepreneurial action thinking, expects the same type and magnitude of contribution from all levels. These are unrealistic expectations and lead to misunderstandings and disenchantment.

To ensure optimum contribution towards greater effectiveness on all levels of management it has to be recognized that executives on different organizational levels operate in different environments. The expected output (contribution) of each major level has to be tailored to the realities of the environment on that level. An illustration of the four major levels of management in any organization coupled to the unique environments (systems) in which these levels operate is supplied in Figure 1 .

The traditional distinction of top, middle, and operational management is expanded to include two middle levels; lower level middle management and higher level middle management. These levels are linked to the two major operating environments, or systems, found in modern business organizations; the closed and the open system.

The closed system is not an organically closed entity. Higher levels of management create an artificially closed environment for lower levels of management. This is achieved through stock control, preventative maintenance, production planning and control, industrial relations, and other applicable systems which buffer the lower level managerial job incumbent against unexpected and largely uncontrollable changes in the environment.

This buffering effect is obviously impossible to achieve 


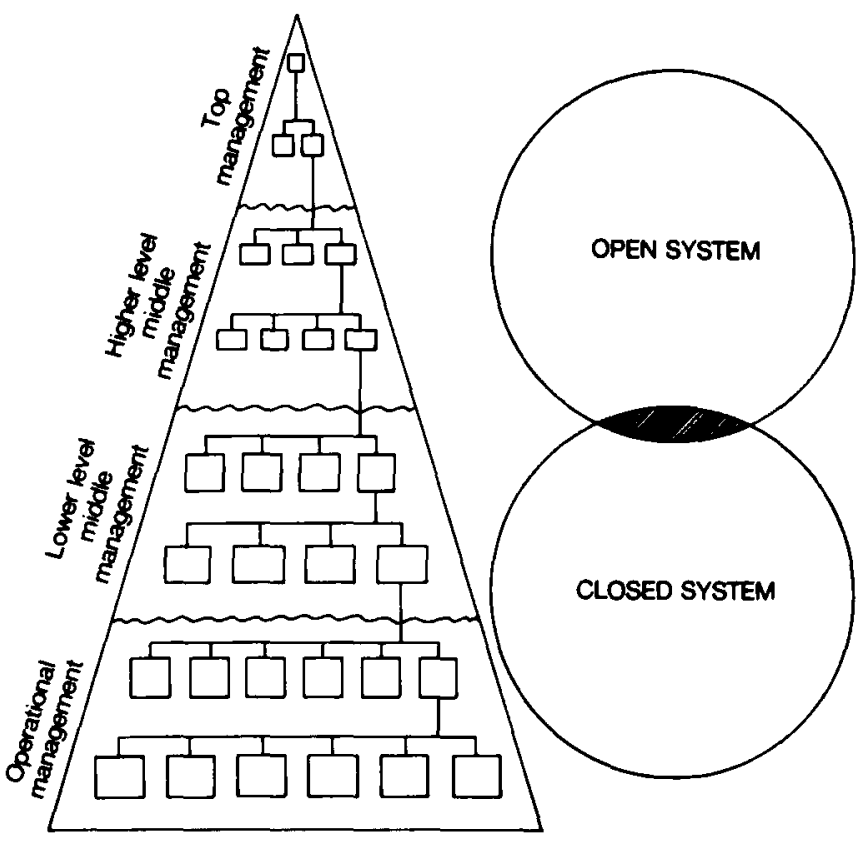

Figure 1 Hierarchical operating environments

at the higher levels of management. Executives on these levels are almost completely exposed to the full effects of environmental turbulence. They can accordingly, be described as operating in an open environment (system).

\section{Operational level management}

In a manufacturing organization, the positions of foreman and production superintendents are typically regarded as operational level management. In service concerns this managerial level usually consists of positions like chief clerks and section leaders. Referring to Figure 1, it is evident that this level in the organizational hierarchy operates in the closed system. As such, good performance on this level implies efficiency. Efficiency in turn, implies the achievement of pre-determined operational standards. Such standards are usually expressed in terms of time, quantity, quality, and cost considerations. The process of control applicable to this level of management has been illustrated by Schutte (1981: 117) (Figure 2).

Satisfactory performance is measured by the achievement of the standard. Non-achievement leads to corrective action, which normally takes the form of adjustments to the inputs or to the physical system, to achieve actual output results which conform to the standard. The contribution of operational level management has traditionally been seen in this light: achieving optimum performance by conforming as efficiently as possible to established work systems, procedures, and methods.

However, in recent years, the observation has been made with increasing frequency, that operational level managers can be a valuable source of innovation. Daily contact with problems and opportunities encountered at the rock face, places such persons in a very good position to identity and communicate potential improvements to operations.

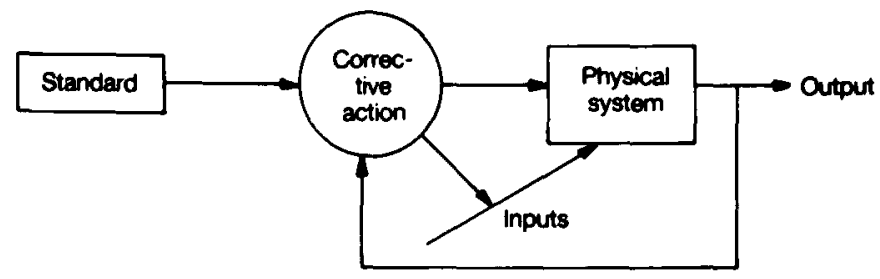

Figure 2 Operational level control model

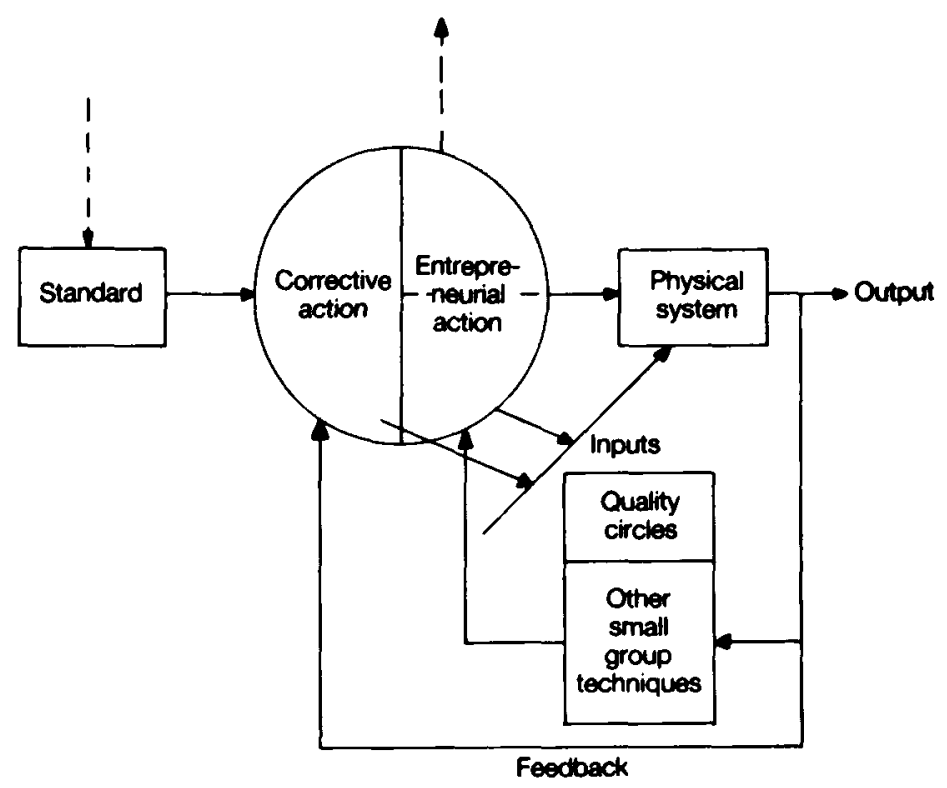

Figure 3 Expanded operational level control model

Recognition of this necessitates an adjustment to the applicable control model (Figure 3).

Operational competencies, deficiencies, and opportunities are picked up at the output phase. This forms the basic input to small group entrepreneurial action thinking. The output of this process leads either to improvements to the input process or the physical system, or both, being implemented by the operational level management or to the communication of such potential improvements to lower level middle management for ratification and approval.

To enable optimum performance in this regard, higher level management should ensure that the operational level managers are granted authority commensurate with responsibility for the implementation of approved recommendations.

\section{Lower level middle managernent}

This level of management operates in both the closed as well as the open system. However, involvement is much greater in the closed environment. The process of control applicable to this level is illustrated in Figure 4.

To ensure optimum creative performance on this level, a predictive control aspect is added to the basic control model. In Figure 4 the feedforward line denotes the predicted economic performance of the organizational segment under the control of the affected lower level middle manager. 


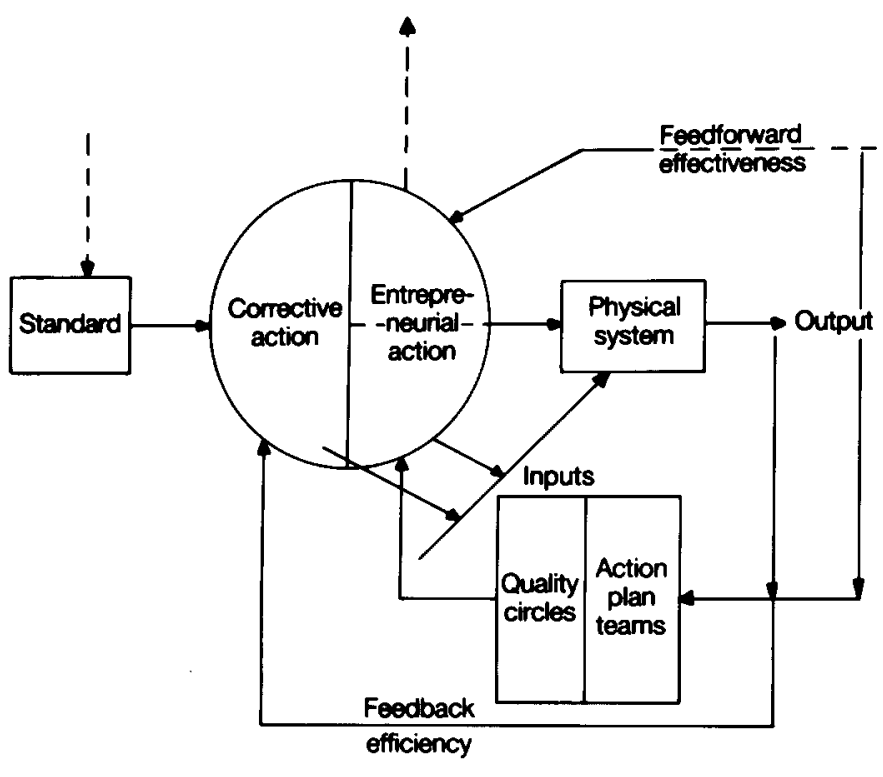

Figure 4 Lower level middle management control model

Excellent performance on this managerial level demands efficiency; achieving optimum input-output relationships, as well as effectiveness; the continuous development of entrepreneurial plans and action programmes aimed at achieving the standards and objectives of the organizational segment.

\section{Higher level middle management}

Divisional, functional or departmental managers are representative of this level of mangement. As can be seen from Figure 1, such executives operate almost exclusively in the open system. Accordingly, effectiveness is of the utmost importance. The major responsibility of this managerial level is to optimize the contribution towards overall company objectives of the division, department, or function under their control. Figure 5 illustrates the process of control applicable to this level. This model is an adaptation of the management control model developed by Schutte (1981: 133).

This model differs from the models applicable to the two lower levels of management in the following respects:

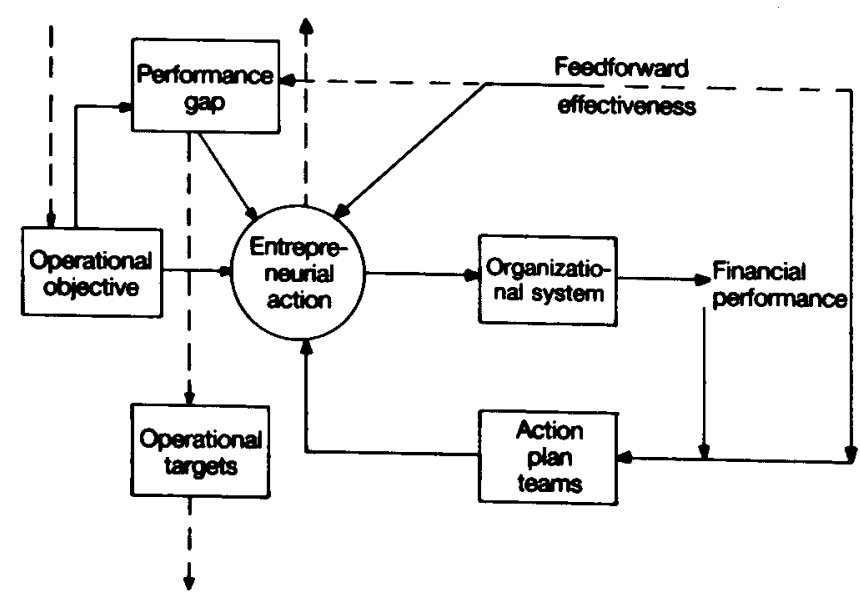

Figure 5 Higher level middle management control model
- performance is measured in terms of deviations from an operational objective ${ }^{1}$ and not an operational standard;

- appropriate managerial action in the case of deviations from the operational objective consists of the development of entrepreneurial action plans. The objective is to improve on any situation as it develops, whether this situation is favourable or unfavourable. Corrective action plays a small role on this level;

- the model represents the organizational segment, division, department, or function under the control of the affected higher level middle manager, rather than the physical system.

The prime motivator of entrepreneurial action on this level is the performance gap. This gap develops as a result of deviations between the predicted financial performance and the operational objective of the affected organizational segment. The performance gap, which is usually updated on a montly basis stimulates creative managerial action to attempt to close or minimize the gap. This gap consists of two elements, namely an efficiency gap and an effectiveness gap.

The efficiency gap should be closed by means of corrective action and the optimization of the inputoutput relationship. This is a typical Management by Objectives (MBO) exercise where an operational target is periodically set by superior and subordinate consensus. Such a target usually represents some achievable improvement over the established standard against which performance is presently being measured.

The appropriate relationship is illustrated in Figure 5 by means of the dotted line leading from the performance gap to the operational targets which are set for the lower level middle managers and have an impact on their standards (Figure 4).

To the extent that the limits of efficiency improvements have been attained and a gap still exists, this gap should be closed by means of higher level middle management action. The appropriate action here consists of entrepreneurial action plan development.

\section{Top level management}

The major objective of this level of management is the optimization of the long-term performance of the organization as a whole. The control process applicable to this managerial level is illustrated in Figure 6.

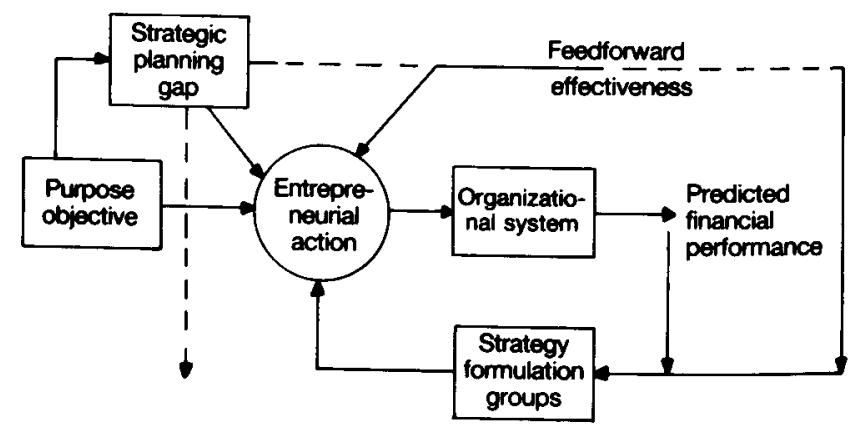

Figure 6 Top level management control model 


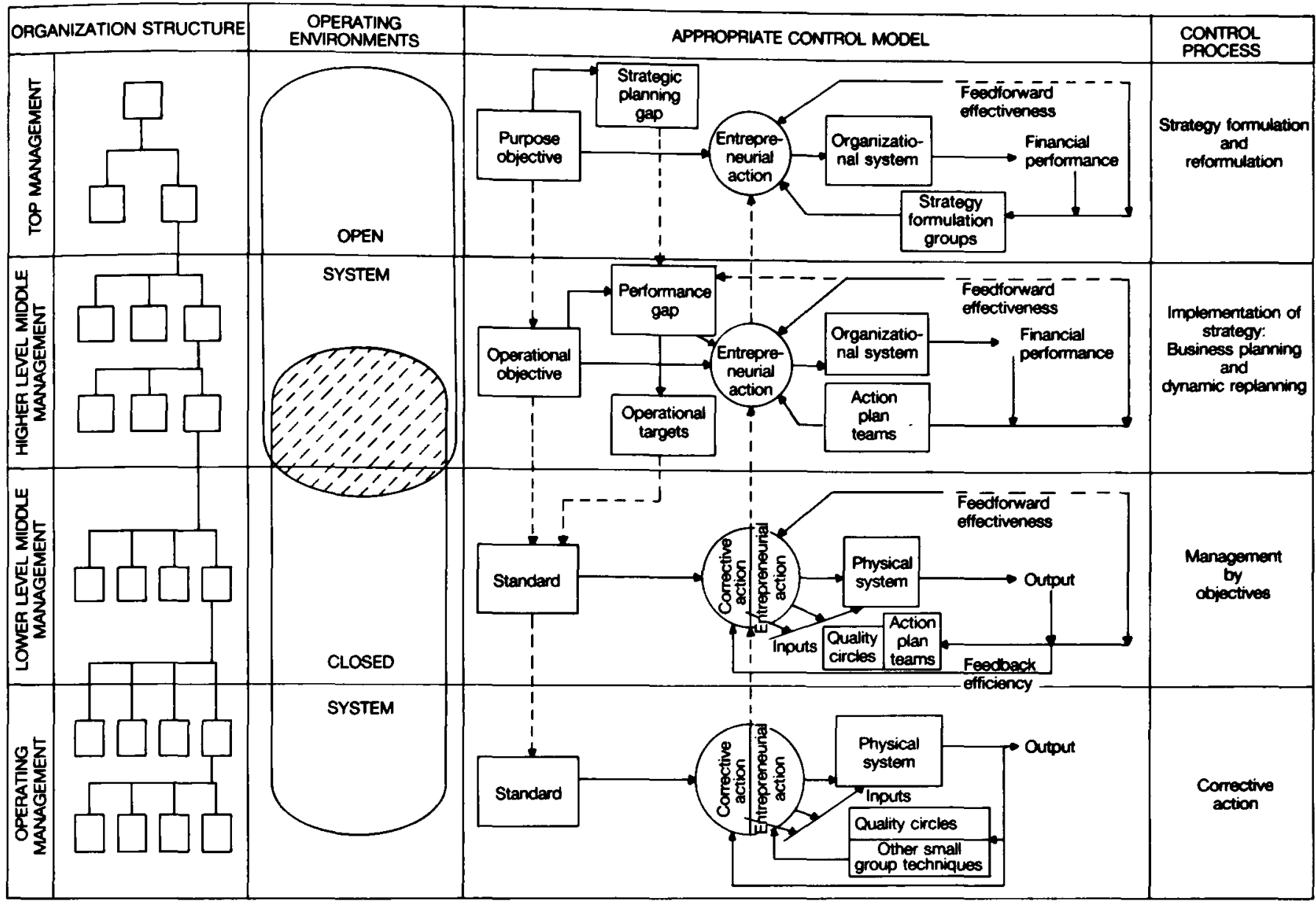

Flgure 7 Entrepreneurial action thinking: an integrated perspective

On this level, performance is measured in terms of deviations of anticipated financial performance from a purpose objective ${ }^{2}$. Such deviations result in a strategic planning gap. Contributions to such an overall gap, arising in a particular division, department or function is cascaded downwards and affects the operational objective of that organizational segment (Figure 5). Any gap remaining after optimum performance from the lower levels of management has to be closed by top management entrepreneural action. This action usually takes the form of formulation and reformulation of strategies and the planning and replanning of major action plans.

\section{An integrated perspective}

In Figure 7 the four major managerial levels are identified and superimposed. The operating environment encountered on each level is linked to that particular level and the model of control appropriate to that environment, reproduced. The integrative mechanisms, linking certain elements of a particular control process with the affected elements of the other processes, are shown by means of the dotted lines. The purpose objective of the top management level has a major influence on the operational objective of the higher middle management level which, in turn, influences the standards of the lower middle management and the operating mangement level.

The strategic planning gap leads to the cascading of performance gaps to the higher middle management level which in turn results in the dissemination of operational targets to the two lower managerial levels. The targets influence the standards applicable to these levels.

Entrepreneurial action developed on each level affects the appropriate higher level. Action plans and strategies have to be submitted for approval to higher levels and may thus stimulate creativity on the higher levels.

The last column of Figure 7 describes the nature of the control process applicable at that level to derive optimum creative managerial reaction to changing circumstances and to deviations from standards, targets, and objectives. The appropriate action on the operating management level consists of corrective action. On the lower level middle management level, corrective as well as entrepreneurial action is appropriate. The process best suited to bring about the optimum compromise between these two actions is Management by Objectives. The implementation of strategies developed on the top management level is undertaken on the higher middle management level by means of a planning and replanning process. Creative managerial action thinking on the top management level results in the formulation and reformulation of strategies. 


\section{Conclusion}

To ensure profitable growth over the long term, any business organization has to utilize fully the inherent entrepreneurial ability of its management team. To this end, the organizational control systems should be developed and operated in such a way that this creative energy is unleashed and directed in suitable channels. Control models, which should aid top management in achieving this desirable result, were developed or adapted from existing models. An attempt was made to provide an integrative perspective on the vital matter of creativity in business organizations by linking the identified control elements, on each managerial level, with the affected elements on the higher level.

\section{Notes}

1. Operational objectives are the end results of the annual business planning (budget setting) process and reflect what the division, department, or function believes it can do and achieve.

2. A purpose objective is a statement reflecting what the organization believes it should do and achieve. It reflects top management's perception of the wishes of the stakeholders of the company.

\section{Reference}

Schutte, F.G. 1981. Integrated Management Systems. Durban: Butterworths. 